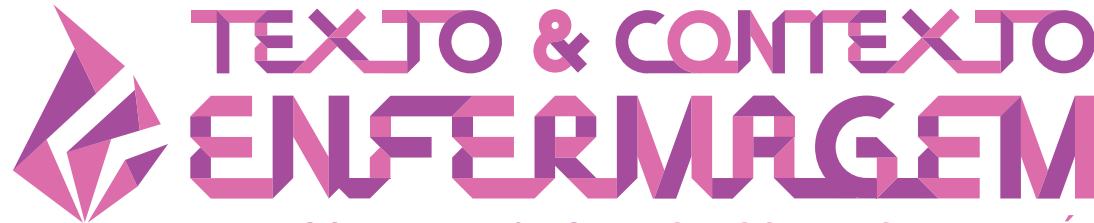

TEXT \& CONTEXT NURSING TEXTO \& CONTEXTO ENFERMERÍA

\section{MEANINGS OF WORK: ARTICULATION \\ WITH MECHANISMS OF RISK AND \\ PROTECTION FOR RESILIENCE}

\author{
lluska Pinto da Costa ${ }^{1}$ (B) \\ Danielle de Araújo Moreira ${ }^{1}$ (iD \\ Maria José Menezes Brito' ${ }^{1}$ (D) \\ ${ }^{1}$ Universidade Federal de Minas Gerais. Belo Horizonte, Minas Gerais, Brasil.
}

\begin{abstract}
Objective: to understand how the meanings attributed to work by professionals of the Family Health Strategy are linked to the mechanisms of risk and protection, influencing resilience.

Method: a qualitative case study, conducted with professionals of the Family Health Strategy. 62 professionals participated: 14 doctors, 16 nurses, 16 nursing technicians and 16 community health agents. The data collected through interviews which were guided by semi-structured script and observation were submitted to thematic content analysis and Atlas.ti Software, version 7.

Results: adversities in the work environment emerged from the analysis such as work overload, lack of articulation between health network services, insufficient autonomy and recognition and inadequate working conditions. Such experiences imply risks to the meanings and the development of work, limiting more resolute actions in the care of the population. Mechanisms that provide protection against risks were also highlighted, strengthening the positive meanings given to work that favor resilience.

Conclusion: the study made it possible to understand how the meanings attributed to work are linked to risk and protection mechanisms, influencing resilience processes. Such reflections can support strategies to reduce adversity in the work environment, stimulate the professionals' potentialities and positive senses about work, aiming at reaching a healthy work environment, which affect the care actions to the population.
\end{abstract}

DESCRIPTORS: Family Health Strategy. Health professionals. Job. Psychological resilience. Risk factors. Protection factors. 


\section{SENTIDOS DO TRABALHO: ARTICULAÇÃO COM OS MECANISMOS DE RISCO E PROTEÇÃO PARA RESILIÊNCIA}

\section{RESUMO}

Objetivo: compreender como os sentidos atribuídos ao trabalho por profissionais da Estratégia Saúde da Família se articulam aos mecanismos de risco e proteção, influenciando a resiliência.

Método: pesquisa de abordagem qualitativa, do tipo estudo de caso único, realizada com profissionais da Estratégia Saúde da Família. Participaram 62 profissionais: 14 médicos, 16 enfermeiros, 16 técnicos em enfermagem e 16 agentes comunitários de saúde. Dados coletados por meio de entrevista, guiada por roteiro semiestruturado e observação, sendo submetidos à análise de conteúdo temática e ao Software Atlas ti, versão 7.

Resultados: da análise, emergiram adversidades no ambiente laboral relacionadas à sobrecarga de trabalho, ausência de articulação entre os serviços da rede de saúde, autonomia e reconhecimento insuficientes e condições de trabalho inadequadas. Tais vivências implicam riscos aos sentidos e ao desenvolvimento do trabalho, limitando ações mais resolutivas no cuidado à população. Foram evidenciados, também, mecanismos que conferem proteção diante dos riscos, fortalecendo os sentidos positivos conferidos ao trabalho que favorecem à resiliência.

Conclusão: o estudo possibilitou compreender como os sentidos atribuídos ao trabalho se articulam aos mecanismos de risco e proteção, influenciando processos de resiliência. Tais reflexões podem subsidiar estratégias de redução de adversidades no ambiente laboral, estimular as potencialidades dos profissionais e sentidos positivos sobre o trabalho, com vistas ao alcance de ambiente laboral saudável, que repercutam nas ações de cuidado à população.

DESCRITORES: Estratégia Saúde da Família. Profissionais de saúde. Trabalho. Resiliência psicológica. Fatores de risco. Fatores de proteção.

\section{SENTIDOS DEL TRABAJO: ARTICULACIÓN CON MECANISMOS DE RIESGO Y PROTECCIÓN DE RESILIENCIA}

\section{RESUMEN}

Objetivo: comprender cómo los significados atribuidos al trabajo por parte de los profesionales de la Estrategia de salud familiar se articulan con los mecanismos de riesgo y protección, influyendo en la resiliencia.

Método: una investigación de enfoque cualitativo, un estudio de caso único, realizado con profesionales de la Estrategia de Salud Familiar. Participaron 62 profesionales: 14 médicos, 16 enfermeras, 16 técnicos de enfermería y 16 agentes de salud comunitaria. Los datos recopilados a través de entrevistas, orientas por guiones semiestructurados y observación, se enviaron a análisis de contenido temático y Atlas ti Software, versión 7.

Resultados: del análisis surgieron adversidades en el entorno laboral relacionadas con la sobrecarga de trabajo, falta de articulación entre los servicios de salud, autonomía y reconocimiento insuficientes y condiciones de trabajo inadecuadas. Esas experiencias implican riesgos para los sentidos y el desarrollo del trabajo, limitando acciones más resueltas en el cuidado de la población. También se evidenciaron mecanismos que brindan protección contra los riesgos, fortaleciendo los significados positivos dados al trabajo que favorecen la resiliencia.

Conclusión: el estudio permitió comprender cómo los significados atribuidos al trabajo están vinculados a los mecanismos de riesgo y protección, influyendo en los procesos de resiliencia. Esas reflexiones pueden apoyar estrategias para reducir la adversidad en el entorno laboral, estimular el potencial de los profesionales y los significados positivos sobre el trabajo, con el objetivo de lograr un entorno laboral saludable, que tenga un impacto en las acciones de atención para la población.

DESCRIPTORES: Estrategia de salud familiar. Profesionales de la salud. Trabajo. Resiliencia psicologica. Factores de riesgo. Factores de protección. 


\section{INTRODUCTION}

The Family Health Strategy (FHS) is one of the main initiatives for strengthening and consolidating the Unified Health System (Sistema Único de Saúde - SUS), and is considered a priority tool for restructuring Primary Health Care in Brazil, with increasing expansion throughout the national territory. In addition, it seeks to reorient the care model, based on the process of building new practices, in order to revert the previous curative model of health care, to a preventive and health-promoting perspective, which enables positive impacts on the population's health conditions. ${ }^{1-2}$

In order to meet the principles of Primary Care, it is essential that professionals consider the singularities and historical-cultural context of users, in order to provide comprehensive and resolute care. In addition, the importance of longitudinal actions and a holistic view on the population's health needs should be highlighted, integrating health care and promotion. ${ }^{3}$

The actions in the FHS are based on teamwork, which contributes to the development of practices provided to families in assigned territories, which include welcoming and establishing links with the community. These actions play an essential role in the first contact with the user, constituting the basis for the organization of care networks, supported by diagnostic, specialized hospital care services. ${ }^{2-3}$

The model proposed by the FHS gives rise to new and constant challenges for workers in this scenario. In working experiences, professionals deal with complex situations, high degree of demands and responsibilities, which, combined with the confrontation with various barriers to professional performance, hinder or limit the development of work activities, making them susceptible to the impact of internal and external stressors. ${ }^{4}$

This reality represents health risks for professionals, which may trigger psychological distress and compromise the meanings they attribute to their own work, affecting the care provided to users. Thus, the complexity of situations that exist in the dynamics of work in the FHS requires professionals to have skills to deal with the numerous situations experienced in the workplace. ${ }^{4-5}$

In contrast to this adversity scenario, research has highlighted the importance of understanding positive aspects of work environments and promoting healthy and protective conditions for professionals by promoting resilience. A healthy work environment encourages workers to cope with adverse conditions through positive and persevering attitudes in order to enable dynamic balance during and after unfavorable circumstances. ${ }^{6-7}$

Historically, pioneering studies in the 1970s addressed resilience as a trait, an innate ability that allowed the individual to be immune or resist adversity. Since the 1990s, research has been developed in order to broaden definitions and knowledge on the subject, changing the direction of studies and thinking of scholars, initially, focused on the individual, for approaches that consider resilience as processes of development. ${ }^{8-17}$

Given the theoretical and conceptual diversity that permeates the scientific literature on the construct, this research was based on the studies on resilience developed by Rutter, ${ }^{9-12}$ Walsh ${ }^{13-14}$ and Yunes, ${ }^{15}$ which show that resilience consists of processes during the life cycle, which involve the relationships and the context in which the individual is inserted, as essential dimensions for their own development, enabling the human being to face and respond positively to the adversities of daily life.

Therefore, resilience can be conceptualized as a set of life processes that enable individuals, groups or communities to cope with and overcome negative experiences and adversities, with consequent positive development, strengthening, learning and personal and contextual transformations. ${ }^{15}$ It is a dynamic phenomenon, developed from the interrelationships between the individual and the family, social and cultural context in which they are inserted, allowing the person to be able to deal with situations positively and strengthen their adversities. ${ }^{13-16}$ 
Resilience, understood as a dynamic process, consists of mechanisms that include risk and protection factors, which underlie its development. Risk mechanisms include negative life events, environmental or individual, that affect the vulnerabilities of the person and may cause negative results and influences on physical, mental or social development, depending on the severity, duration and frequency. It is noteworthy that risk should not be thought of as a static factor, considering that it depends on the context in which it operates, which involves a complex network of events before and after the adverse event. ${ }^{9-11}$

Protection mechanisms act to reduce, mitigate or avoid the impact of risks, enabling individuals to seek solutions that may change or improve the response to the adverse situations experienced. Thus, resilience is the end product of protective mechanisms or processes that do not eliminate risks but strengthen the individual to engage in and cope effectively. ${ }^{9,11}$

It is necessary to understand how protection mechanisms or processes can enhance resilience in the face of adversity and risk. To this end, Walsh ${ }^{13-14}$ points out elements that integrate key family resilience processes and may be applicable to other groups in different contexts. Among the elements that make up these processes, the following stand out for this study: spirituality, faith, good humor, optimism and mutual support.

Walsh's ${ }^{13-14}$ conceptions provide support to understand resilience in the health work scenario, considering that these processes are developed through affective bonds formed in the positive relationships and mutual help of professionals with the team, the community and other elements in the context in which they are inserted.

In this approach, the work environment can provide space for reflection on practices, aspirations and other aspects present in the professionals' experiences, making it possible to develop learning and potentialities, through relational strategies and mutual help. These attributes allow professionals to fight and face obstacles more effectively.

It emphasizes the meaning and perception attributed to experiences in the workplace for resilience processes, considering that their development is related to the way in which the individual internalizes and develops a situation, and can be understood as adverse or not, which it favors the possibility of the human being to face and redefine the negative events in positive ones. Thus, the meanings given to work may represent risk or protection and influence the way a person acts in the face of adversity. ${ }^{13-14,17}$

In this study, the meanings of work were considered according to the approach presented by Morin, ${ }^{18-19}$ in which characteristics necessary for work to make sense are mentioned, such as: being performed efficiently and generating useful results; enable satisfaction in the development of activities; allow the worker to use talent and potential autonomously; be morally acceptable; be a source of satisfactory human relations; enable financial security, connected to a salary that ensures survival and keep people busy, avoiding anxiety.

Although studies have analyzed the relationship between risk and protection mechanisms for resilience at the national and international levels, there are still few studies that address how the meanings attributed to work articulate with these mechanisms and influence resilience processes. This reality highlights the gap in the knowledge, especially regarding work in the FHS, considered the main entrance to the Health Care Network. ${ }^{3}$

By considering the particularities and complexities that involve the experiences in the FHS and the relevance of the theme for professional practice, this study aimed to understand how the meanings attributed to the work by FHS professionals are articulated with the mechanisms of risk and protection, and influence the promotion of resilience. 


\section{METHOD}

This is a qualitative case study that allows us to understand a phenomenon that involves a real-life context, allowing the researcher to grasp in depth the significant characteristics of the events. The case study in qualitative research should contemplate different sources of evidence, which make the results more consistent, allowing data triangulation, thus meeting the criteria related to the construct validity. ${ }^{20}$

The study was carried out in all FHS units of the Alto Sertão municipality of Paraíba State, Brazil, from February to August 2017. The state has a population of 3,996,496 inhabitants, with $95.63 \%$ coverage of the FHS, with an estimated covered population of $3,822.21$. The municipality in the study scenario is $100 \%$ covered by the FHS teams, whose covered population corresponds to 61,776 . The municipality has 23 FHS units, 17 located in the urban area and six in the rural area. ${ }^{21}$

Professionals from the categories that make up the FHS basic team participated in the study: doctor, nurse, nursing technician and community health agents. In all units, the teams consisted of one professional from each category, except for community agents that ranged from five to 10 agents per health unit, depending on the population contingent of each area. Thus, it was decided to choose a community agent from each of the units to compose the study.

The inclusion criterion for the participants was to have more than or equal to six months of professional experience in the FHS unit in which they were working, considered a necessary period for the participants to experience the work dynamics and to know the community better. Sixty-two professionals working in the $23 \mathrm{FHS}$ units participated in the study. Thirty participants were excluded: 17 refused to participate $(56.3 \%)$, nine had less than six months of professional experience in the service $(30.0 \%)$, three were on vacation $(20.0 \%)$ and one was on medical leave $(3.3 \%)$.

Two sources of evidence were used in the study: interviews, guided by a semi-structured script, and observation. The interview included questions aimed at characterizing the participants' sociodemographic profile and open questions pertinent to the object of study, focusing on the aspects: work environment, organizational, interpersonal relationships, experiences of adversity that imply work risks, internal and external protective factors at work, strategies used to deal with adversities, meanings offered to work through experiences of risk and protection.

The interviews lasted 60 hours in total and were conducted by the researcher, individually, in a reserved space, in the FHS unit itself, respecting the availability of professionals. The statements were recorded and transcribed in full.

The observations are a source of evidence for the study, and were performed during the data collection period, in all health units, and finished only at the end of this period. They occurred in moments prior to the interview, in areas of the FHS units, such as the reception, a meeting room and the cafeteria, places that allowed the researcher to observe the dynamics of the workplace. In these areas, it was possible to pay attention to the arrival and departure of people, the reception of users, the organizational flow of care, communication between professionals, some moments of relaxation and meetings, as well as some situations of conflict and disagreement between professionals and the community. Observations were recorded and identified as observation notes (ON).

The analysis of empirical data was performed using the thematic content analysis proposed by Bardin, ${ }^{22}$ including the steps of pre-analysis, material exploration, treatment of results, inference and interpretation. Atlas.ti Software, version 7, was used as an operational tool for interview analysis. In the pre-analysis phase, the material was inserted in the program and the floating reading of the interviews was performed, which contributed to the visualization and organization of the data. In the data exploration phase, the software facilitated material management for code creation and categorization. Categorization was performed in ATLAS.ti by organizing codes by common characteristics or by 
relevance, culminating in the creation of families. Regarding inference and interpretation, the software favored the visualization of the codes present in each family, which contributes to the interpretation and discussion of the findings. ${ }^{23}$

The study complied with the formal requirements of Resolution No. 466/2012 of the National Health Council, which regulates research involving human subjects, and was approved by the Ethics Committee. Participants signed the Informed Consent Form. In order to ensure anonymity, and participants were identified with the initials of the professional category: Nurses- $\mathrm{N}$; Nursing techniciansNT; Physician-P; Community Health Agent-CHA, followed by the numerical order of interviews.

\section{RESULTS}

Among the 62 professionals who participated in the research, 14 were doctors $(22.6 \%), 16$ nurses (25.8\%), 16 nursing technicians (25.8\%) and 16 CHAs (25.8\%). Most professionals were female $(85.5 \%)$, aged between 30 and 39 years $(48.4 \%)$, married or in a civil union $(48.4 \%)$, with between one and five years $(37.1 \%)$ of professional experience in the unit and who had no other employment relationships $(67.7 \%)$.

The following categories emerged during data analysis: Directions attributed to work in the FHS: articulations with risk mechanisms; Meanings attributed to work and protection mechanisms: Articulations that favor the development of resilience.

\section{Meanings attributed to work in the FHS and risk mechanisms}

The results that make up this category revealed that the experiences in the FHS were permeated by adversities and risks that may denote unfavorable effects to the physical, social and/or emotional environment of the professionals. In addition, the risk mechanisms present in the FHS work environment may have negative implications for the meanings that professionals attribute to their own work, which, in turn, interferes with care actions.

In addition to the adversities identified by the participants in the work environment, the following stand out in this study: lack of articulation between the network services, precarious working conditions, lack of autonomy and recognition, overload, excessive care and bureaucratic demands. The reports showed that these conditions have negative effects on work and produce psychological risks for professionals, such as anguish and suffering, which can compromise the health and well-being of professionals and cause implications to the care provided to the community.

The lack of articulation between the health network services, as well as the inadequate working conditions regarding infrastructure, material scarcity, resources and transportation, were also referred to as adversities that interfere with the work organization and resolution of actions:

The network does not work as it should. Sometimes the patient needs specialist consultation, or even urgency, which takes four or five months. That is if you can get an appointment. So, what's the point? By the time he is successful, the patient already has a more serious condition and may not even be able to reverse his situation (CHA 12).

There are many daily difficulties: not enough resources to work, lack of EPI. The environmental and physical conditions here in the countryside are precarious and need to be improved. There is also a lack of transportation to go to the patient's house to provide care. I often ride a motorcycle with the CHA. You can feel people's anger at the delay in scheduling an exam, a surgery (T15).

The lack of network articulation and poor working conditions are in line with the data obtained from the observation. In the reception environment, in one of the FHS units, complaints and user irritability were observed due to excessive waiting time for exams or consultations with specialists, 
causing conflicts between the receptionist and population. In addition, the explanations provided to users by the nursing technician about the scarcity of dressing materials were observed. (ON)

Insufficient autonomy and recognition were mentioned as risk factors that:

Cause the professionals to feel of devalued, compromising the meaning and performance of activities:

I am dissatisfied, for wanting to do the best for the population and not having enough autonomy, to be able to do what I have learned, the new strategies of the Ministry of Health, to want to implement and there is no support. It makes the person sad, discouraged, you know? (P12).

We are seen as a health clinic nurse, a health clinic doctor! We are classified like this a lot. There is little recognition of the importance of our work. There is still a sense of devaluation, for the FHS and the professionals. This is the perspective of part of the community, but also for health management, including who should value it (N9).

The situations of organizational and structural adversities mentioned, added to the excess of care and bureaucratic demands, lead to work overload for FHS professionals, causing health repercussions and compromising work performance:

What I see in my work is the pressure on the professional, I feel very pressured, overworked, tired, sometimes suffocated. There are many tasks, difficult situations that require responsibility and that often cannot be solved (N9).

The excessive amount of bureaucratic tasks was mentioned by nurses, as according to these professionals, it keeps them from actions with the community, interfering in the meaning of care:

My activities are affected because I have to take care of bureaucratic and managerial tasks. I am dissatisfied, because the real meaning of my job, caring, is limited (E13).

All bureaucratic issues and human resources of the unit are the nurse's responsibility, so we have to work extra hard to also provide care, compromising our actions that should be mainly related to care (N5).

The obstacles linked to the lack of integration of the health network, inadequate working conditions, insufficient recognition and autonomy, as well as the overload and excess of bureaucratic demands revealed in the statements, makes it impossible for professionals to effectively perform their work, or provide more dedicated care to the population.

The factors mentioned by the participants show feelings, such as sadness, anger, helplessness, frustration and discouragement, which, in turn, cause feelings of dissatisfaction and non-accomplishment with their work or even the loss of meaning regarding the activities performed. These aspects culminated in psychological risks, such as anguish, suffering and even conditions of illness.

However, the action of these risk mechanisms may compromise the care provided to the community, as evidenced in the reports:

I get very frustrated! There are specialties that SUS does not have in the city and the patient who urgently needs it, has no money to look for. So, I get "aperreada" [Northeastern term meaning agony, anger]! I get sad, angry, distressed, tormented (P8).

Because when you are working in an environment that is not recognized or has no autonomy, no support to deal with situations, you become discouraged, feel helpless, you do not feel fulfilled, it is not rewarding there. Sometimes you even lose the meaning, the satisfaction, for the work. This causes me anguish and I suffer because of it (N1).

We deal with various difficulties of daily work that often cannot be solved. This is overwhelming, distressing. So, we put them under the carpet, develop control mechanisms, until we explode. I got sick during this period of stress. I was tired, angry and unmotivated, I could not do my job well, I did not feel fulfilled [...] until another doctor colleague diagnosed me with Burnout syndrome (P9). 


\section{Meanings attributed to work and protection mechanisms: articulations that promote resilience}

The statements revealed protection mechanisms linked to personal and relational aspects, which enabled professionals to build or enhance positive meanings about their own work, motivating them to seek solutions when faced with risk situations. Factors such as faith and spirituality, good humor, optimism and mutual support were revealed as elements that promote resilience in professionals in the context of working at the FHS.

Spirituality and faith emerged as protective factors that favor the personal empowerment of professionals, so as to face adversity positively and wisely, giving meaning to the experiences:

But, we always try to take a moment here in the unit, this moment is for the team, to thank God first, to ask Him to bless us, to give us wisdom, to give us strength to overcome difficulties, for us be able to help and be useful to people through our work (N8).

In addition, faith associated with the sense of helping and being helpful enabled professionals to perceive difficulties as challenges:

My work makes sense, because I can help someone, because I feel useful when I see that the user is satisfied, and that makes me want to continue in my position as technician. My faith and willingness to help make the challenges in my work small (NT15).

The participant's report N8 is consistent with what was observed in the work scenario. At the beginning of work, it was possible to witness a moment of prayer among some team members. The occasion was marked by moments of emotion and demonstrations of integration between the participants (ON).

Good humor and optimism strengthen feelings of satisfaction and identification regarding work, providing protection against adversity. These mechanisms favor resilience as they encourage professionals to deal with risk situations in the workplace:

I think every day when we wake up, and come to your work environment, happy, and come in smiling and leave smiling, you are doing something with pleasure, with satisfaction. This strengthens us and helps us to cope with difficult situations on a daily basis (NT10).

The point of my job is to be optimistic, to see the positive side of situations. This is how we can face the difficulties here in the sertão. We need to be optimistic; we have to like and identify with what we do to continue to fight and seek the best for the community. So, it makes sense to be a Health Agent (ACS 5).

The reports converge with some situations observed throughout the data collection period. In some FHS units, it was possible to witness moments of interaction and relaxation between team members, which occurred in the cafeteria of the units, on short breaks or at the end of the work period. At these meetings, professionals took the opportunity to share news, fun situations and personal aspirations. In some scenarios, humorous interaction between users and professionals were observed, making the work environment more relaxed and welcoming (ON).

Mutual support in interpersonal relationships in the workplace has emerged as a protective factor that enhances the sense of teamwork, becoming an element that facilitates the search for solutions when faced with difficulties and the development of resilience:

The teams I work with have like-minded people, got it? They like the FHS, they want to see the work done well. This makes it much easier (P1).

We give support to each other in our team. So, we help and motivate each other. These are people who say: I need help! If I don't have the solution at that time, the team tries to look for a way out (CHA 5). 
CHA 5's statement is in line with what was observed during a meeting between nurses, nursing technicians and community health agents, which was witnessed by the researcher. At this meeting, the community health agents shared anxieties, difficulties with the other professionals and jointly sought solutions to the problems, even with the existing limitations. This moment revealed potentialities to promote resilience, both individually and in teams, through mutual support relationships and integration between professionals (ON).

\section{DISCUSSION}

The study revealed that the situations of adversity experienced in the work environment of the FHS may pose risks to professionals and their performance. The risk factors mentioned in the study focus on interactions that translate into mechanisms, negatively affecting different aspects, either in the meaning attributed to work, the psychological scope or the care provided to users and the community.

Work-related adversities were mentioned in this study, most of which are associated with the organizational and management aspects of the FHS. Participants mentioned difficulties related to the lack of articulation of the health network, poor working conditions, lack of recognition and insufficient autonomy and work overload of professionals, as factors that pose risks to the meaning and development of work activities. The aspects mentioned by the professionals aimed to limit a broader approach to the problems of the population, as well as the implementation of more effective actions that can respond to the real needs of the community.

The findings that emerged in the present study were also highlighted in other research as factors that presuppose the exposure of professionals to psychosocial risks in the workplace, which impact health and work performance..$^{4,24}$

In line with the results of the present study, research that addressed the context and perceptions of work in primary care revealed that factors related to inadequate working conditions, linked to structural and material aspects, reduced autonomy and lack of recognition for the work performed, support of managers, limit the implementation of strategies according to the principles of $\mathrm{PHC}$, with reflections in the care context, as regards to actions and continuity of the provided care..$^{3,25-26}$

Also confirming the results of this study, regarding the lack of articulation and integration of health network services, another research on the development of the Health Care Network (HCN) in Brazil highlighted that several challenges make it difficult to implement and order the continuity of health care through PHC, including the fragmentation of the provision of health actions and services, the imbalance of human and financial resources and the lack of co-responsibility for care between the various services. These aspects also increase the chance of errors and complications, posing risks to the user and family. ${ }^{27}$

Non-recognition and reduced autonomy promote emotional distress when the worker realizes that the effort is not valued and that the actions have little importance in relation to the needs required by the population. ${ }^{25}$ In this perspective, recognition is extremely relevant for satisfactory work. It consists not only in classifying the professional's performance based on numerical results, but in valuing the quality and intensity of efforts, aptitudes and abilities that allow unique contributions to the actions they perform. ${ }^{26}$

In the present study, the professionals showed feelings of uselessness, frustration, anger and discouragement at work, resulting from experiences of adversity, which resulted in anguish, suffering and even illness. Such mechanisms negatively affect the meaning of satisfaction and fulfillment or may even cause loss of meaning for work, which causes implications for the development of care actions provided to the community.

Regarding these considerations, a study on work dissatisfaction among FHS professionals stresses that feelings of dissatisfaction, fear and frustration may be expressions of overload, stress 
and exhaustion. ${ }^{26}$ Regarding this approach, one study ${ }^{28}$ emphasizes that overwork, emotional stress generated by daily contact with problems of the population, which often involves illness and suffering, discontent and poor interaction between professionals, are relevant factors in relation to the origin of illnesses.

In the reports of the participants of this study, work overload emerged as a risk factor, due to the excessive demands, the need to meet the requirements and goals, as well as the ineffective actions, due to the adversity in the daily lives of FHS workers. The excess of bureaucratic and managerial demand activities were mentioned by nurses especially as activities that cause work overload and which caused them to be removed from care.

Research conducted with FHS nurses on the challenges and potentialities of work revealed that the accumulation of functions of these professionals, which leads to work overload, is linked to accountability for administrative and managerial issues, which limit time and dedication for care actions related to health prevention and health promotion. These aspects make it impossible for professionals to intervene directly in the reality of the community, to understand the territory where the health processes or the illnesses of the subjects, affections and relationships are produced, factors that interfere with the longitudinality of care and the effectiveness of team actions recommended by the FHS. ${ }^{29}$

Still regarding the results of the present study, Burnout Syndrome was mentioned by one of the medical professionals as a consequence of the work overload experienced in the work context. The participant stated that the high demands of work that require great responsibility, which cannot always be solved, cause negative meanings regarding work, as well as physical, mental and social consequences.

In line with this finding, research has been devoted to the study of Burnout Syndrome, recognized worldwide as one of the major psychosocial problems affecting the quality of life of professionals in various areas of work. Burnout Syndrome or "Professional Exhaustion" is a psychological condition, resulting from the chronic physical and emotional tension experienced by the worker, characterized by emotional exhaustion, depersonalization and low personal fulfillment. It produces chronic fatigue or frustration related to people's emotional condition in relation to work and lifestyle, which occurs due to intense dedication to a purpose that does not produce the expected result. ${ }^{28,30}$

Continuing on this issue, research conducted with FHS physicians from the municipality of Minas Gerais, Brazil, revealed that participants had high percentages of risk for emotional exhaustion and depersonalization, due to exposure to high pressures, professional devaluation and care limitations, elements that triggered dissatisfaction and low professional achievement. In addition, professional exhaustion hinders the clinical decision-making process, which can compromise the quality of the services provided and the bond of these professionals with the community, making them less aware and sensitive to the population's problems and increase the chances of abandoning work. ${ }^{30}$

Regarding the mechanisms of risk, the results of this research revealed implications for professionals in different areas. However, given the aforementioned risk situations, some individual and/ or workplace protection mechanisms acted as mediators between the risk mechanism and resilience.

It is evident that the protection mechanisms did not exclude risks, but enabled professionals to enhance skills, assign positive meanings to work, in order to experience and face adversities, thus strengthened by resilience. ${ }^{9}$

In this study, some elements that can promote resilience processes in professionals emerged, ${ }^{14}$ such as: spirituality, faith, good humor, optimism and mutual support. Among the elements mentioned by the FHS professionals, faith and spirituality were revealed as important factors to promote resilience, as they strengthen the condition of facing the risk conditions present in work experiences, acting as 
support in the face of adversity. These elements enhance the identification of professionals with the activities, as well as the sense of usefulness regarding work.

Faith and spirituality enable the person and the group to feel connected with something bigger, which is an important factor of social support, a sense of coherence, hope and motivation that can lead to resilience and empowerment..$^{30}$ One study conducted with FHS nurses reiterates that spiritual empowerment was one of the strategies used by research participants to cope with adversity and distress at work. ${ }^{31-32}$

The feeling of helping and being helpful also emerged in this study as protective factors that allowed professionals to see adversities as challenges. Regarding these aspects, research states that work has meaning if the person doing it has the feeling of overcoming challenges and perceives it as contributing and having responsibility at work. ${ }^{19,33}$

Moreover, attributing challenge to adversity is relevant to the development of resilience. Thus, perception and interpretation of negative experiences, the meaning attributed to a stressful event or relational environment, seen as adverse, may or may not indicate the condition of adversity. For this reason, an event may be faced as a danger by one individual, and for another, a challenge. ${ }^{10-11}$

In the relationship with the team in the FHS organizational environment, mutual support and collaboration among members were identified as an important factor in the protection mechanism for resilience. Support and collaboration among colleagues outweighed the risks associated with insufficient recognition by management or the community itself, providing a source of social support that reinforces the sense of teamwork and motivates professionals to cope with adversity.

In the workplace, social support refers to collaboration, emotional support, and providing solutions for colleagues or supervisors that facilitate work development and are important factors in promoting job satisfaction and well-being. ${ }^{34}$ Resilience can be enhanced by mutual support, collaboration and commitment to addressing difficulties together, with respect for individual needs, limits and differences. ${ }^{13-14}$

In the participants' statements, it was also possible to infer that the sense of humor and optimism are strategies that allow professionals to reevaluate the context of adversity, resignifying and strengthening the meaning of identification and accomplishment through work, which leads to the development of resilience.

Studies have highlighted that a sense of humor is a relevant factor for resilience and wellbeing, while helping to prevent psychological distress. A sense of humor is therefore an effective coping strategy to limit the negative impact of potential stressors, thereby effectively reevaluating the event as less threatening. ${ }^{14}$ Thus, there may be improvements in overall well-being, encouraging attitudes that foster positive relationships, stronger immune responses, greater creativity, altruism, and optimistic vision. ${ }^{35}$

Regarding optimism, this was evidenced in the reports as determinants of positive meanings of identification and satisfaction with work, despite experiences of adversity. The meaning of work favors the identification of professionals with their own work, encouraging them to engage in activities, in view of consistency with values or goals. ${ }^{14,33}$

The findings of the present study revealed that, throughout their work experience, the protection mechanisms enable professionals to assign positive meanings to their work, strengthening resilience processes that allow them to cope with risk situations and to be transformed and strengthened by these, which positively influences well-being and mental health. These transformations also have a satisfactory impact on the care provided, as they enable FHS professionals to learn how to deal with adversities at work satisfactorily. ${ }^{36}$

Given the importance of resilience processes among FHS workers, a better understanding of the multiple dimensions that surround it, as well as the mechanisms that can influence it, becomes 
relevant. Research has emphasized the significance of promoting workplace interventions in order to stimulate processes of professional resilience through practices that value the professional, in needs and potentialities, providing them with opportunities for development and social support. ${ }^{6-7}$

Therefore, it is suggested that places in health units are created in order to listen and discuss the difficulties faced, especially in order to promote joint actions that facilitate the reduction of risks in the workplace, strengthening protection mechanisms and processes in order to promote resilience in professionals.

Regarding the benefits of the method used, the relevance of the case study as a methodological framework is highlighted, allowing the triangulation of the most significant sources of evidence and results, from interviews and observations. In addition, conducting the case study in all scenarios of the municipality's FHS, with the professionals that make up the basic team, provided a comprehensive view of the context.

However, some aspects can be considered as limitations of the study: conducting the interviews in the same scenarios of the participants may have interfered in the statements, due to the fear of exposing problems that involve the work context; and the reduced number of studies that articulate the resilience and meanings of work constructs in the FHS scenario.

\section{CONCLUSION}

The study made it possible to understand how the meanings attributed to work are connected with the mechanisms of risk and protection, in order to influence the promotion of the resilience of FHS professionals. In this context, resilience may represent a new approach to think about the dimension of positivity in the work of professionals when faced with the challenges and adversities in everyday life, with possibilities for learning and transformations that may have repercussions in practice.

The FHS professionals mentioned experiences of adversity related to inadequate working conditions, as well as organizational and management aspects, which hinder actions directed at the population. Such circumstances caused the professionals to experience psychological repercussions, such as anguish, distress, illness and negativity in relation to the meaning of work which can interfere in the performance of care actions.

The findings also allowed us to understand that when faced with adverse situations that impact on risks, protective mechanisms allowed professionals to give new meanings to their experiences and work. By seeing the adversities experienced in a different perspective, FHS workers are able to positively face the negative impacts from the risk mechanisms and become stronger as a result of this process.

The aim of this study is to support the development of strategies in order to improve the resilience of FHS professionals, as well as to stimulate their potential and the positive meanings they have regarding their work, with a view to achieving a healthy work environment and improving care to the population.

Thus, it is suggested that the study be conducted in other places, in order to encourage new discussions and investigations on the theme, both in the FHS scenario and in different contexts of health work and in the academic field, so that more representative information of the investigated phenomenon can be produced. 


\section{REFERENCES}

1. Malta DC, Santos MAS, Stopa SR, Vieira JEB, Melo EA, Reis AAC. Family Health Strategy Coverage in Brazil, according to the National Health Survey 2013. Ciênc Saúde Colet [Internet]. 2016 [cited 2018 Nov 29];21(2):327-38. Available from: https://dx.doi.org/10.1590/141381232015212.23602015

2. Santos FPA, Acioli S, Machado JC, Souza MS, Rodrigues VP, Couto TA. Care practices of the Family Health Strategy team. J Nurs UFPE on line [Internet]. 2018 [cited 2018 Nov 12];12(1):3643. Available from: https://dx.doi.org/10.5205/1981-8963-v12i01a230589p36-43-2018

3. Ministério da Saúde (BR). Portaria $n^{\circ} 2.436$, de 21 de setembro de 2017. Aprova a Política Nacional de Atenção Básica, estabelecendo a revisão de diretrizes para a organização da Atenção Básica, no âmbito do Sistema Único de Saúde (SUS). 2017 [cited 2018 Feb 23]. Disponível em: http://bvsms.saude.gov. br/bvs/saudelegis/gm/2017/prt2436_22_09_2017.html

4. Araújo ST, Penaforte KL. Psychosocial risks related to work: perception of nursing professionals. J Nurse UFPE on line [Internet]. 2016 [cited 2018 Sept 11];10(11):3831-9. Available from: https:// dx.doi.org/10.5205/reuol.9881-87554-1-edsm1011201603

5. Moreira IJB, Horta JA, Duro LN, Chaves J, Jacques S, Martinazzo K, et al. Aspectos psicossociais do trabalho e sofrimento psíquico na estratégia saúde da família. $\mathrm{R}$ Epidemiol Control Infec [Internet]. 2017 [cited 2018 Sept 11];7(1):1-7. Available from: https://dx.doi.org/10.17058/reci. v7i1.6927

6. Robertson HD, Elliott AM, Burton C, Iversen L, Murchie P, Porteous T, et al. Resilience of primary health care professionals: a systematic review. Br J Gen Pract [Internet]. 2016 [cited 2019 June 11]; 66(647):e423-33. Available from: https://dx.doi.org/10.3399/bjgp16X685261

7. Matheson C, Robertson HD, Elliott AM, Iversen L, Murchie P. Resilience of primary healthcare professionals working in challenging environments: a focus group study. $\mathrm{Br} \mathrm{J}$ Gen Pract [Internet]. 2016 [cited 2019 June 09]; 66 (648): e507-15 Available from: https://dx.doi.org/10.3399/ bjgp16X685285

8. Masten AS. Ordinary magic: resilience processes in development. New York, NY(US): The Guilford Press; 2014.

9. Rutter M. Psychosocial resilience and protective mechanisms. Am J Orthopsychiatry [Internet]. 1987 [cited 2018 Sept 11];57(3):316-31. Available from: https://dx.doi.org/10.1111/j.1939-0025

10. Rutter M. Resilience: some conceptual considerations. J Adolesc Health [Internet]. 1993 [cited 2018 Sept 11]; 14(8):626-31. Available from: https://dx.doi.org/10.1016/1054-139x(93)90196-v

11. Rutter M. Resilience concepts and findings: implications for family therapy. J Fam Ther [Internet]. 1999 [cited 2018 Sept 11];21(2):119-44. Available from: https://dx.doi.org/10.1111/1467-6427.00108

12. Rutter MF. Resilience as a dynamic concept. Dev Psychopathol. 2012;24(1):335-44.

13. Walsh F. Family resilience: A framework for clinical practice. Fam Process [Internet]. 2003 [cited 2019 Jan 27];42:1-18. Available from: https://dx.doi.org/10.1111/j.1545-5300.2003.00001.x

14. Walsh F. Fortalecendo a resiliência familiar. São Paulo, SP(BR): Roca; 2005.

15. Yunes MAM. Dimensões conceituais da resiliência e suas interfaces com risco e proteção. In: Murta SG, França CL, Brito K, Polejack L, editors. Prevenção e promoção em saúde mental: fundamentos, planejamento e estratégias de intervenção. Novo Hamburgo, RS(BR): Synopisis; 2015. p. 93-112.

16. Yunes MAM, Fernandes G, Weschenfelder GW. Intervenções psicoeducacionais positivas para promoção de resiliência: o profissional da educação como tutor de desenvolvimento. Educação [Internet]. 2018 [cited 2019 June 09];41(1):83-92. Available from: https://dx.doi.org/10.15448/19812582.2018.1.29766 
17. Yunes MAM, Garcia NM, Albuquerque BM. Monoparentalidade, pobreza e resiliência: entre as crenças dos profissionais e as possibilidades da convivência familiar. Psicol Reflex Crít [Internet]. 2007 [cited 2019 June 09]; 20(3):444-53. Available from: https://dx.doi.org/10.1590/ S0102-79722007000300012

18. Morin EM. Os sentidos do trabalho. Rev Adm Empres [Internet]. 2001 [cited 2018 Dec 18]; 41(3):8-19. Available from: https://dx.doi.org/10.1590/S0034-75902001000300002

19. Morin EM. Os sentidos do trabalho. In: Wood T. Gestão empresarial: o fator humano. São Paulo, SP(BR): Atlas; 2002. p.13-34

20. Yin RK. Estudo de caso: planejamento e métodos. Porto Alegre, RS(BR): Bookman; 2015.

21. Ministério da Saúde (BR). Departamento de Atenção Básica-DAB. E-Gestor Atenção Básica. [cited 2019 June 06]. Available from: https://egestorab.saude.gov.br/paginas/acessoPublico/ relatorios/relHistoricoCoberturaAB.xhtml

22. Bardin L. Análise de Conteúdo. Lisboa(PT): Edições 70; 2011.

23. Brito MJM, Caram CS, Montenegro LC, Rezende LC, Renno HMS, Ramos FRS. Potentialities of Atlas.ti for Data Analysis in Qualitative Research in Nursing. In: Costa AP, Reis LP, Sousa FN, Lamas AMD, editors. Computer Supported Qualitative Research. Switzerland: Springer International Publishing; 2016. p.71-84.

24. Chagas D. Riscos psicossociais no trabalho: causas e consequências. INFAD Rev Psicol [Internet]. 2015 [cited 2019 June 09];2(1):439-46. Available from: https://dx.doi.org/10.17060/ ijodaep.2015.n1.v2.24

25. Maissiat GS, Lautert L, Pai DD, Tavares JP. Work context, job satisfaction and suffering in primary health care. Rev Gaúcha Enferm [Internet]. 2015 [cited 2019 Jan 07];36(2):42-9. Available from: https://dx.doi.org/10.1590/1983-1447.2015.02.51128

26. Soratto J, Pires DEP, Trindade LL, Oliveira JSA, Forte ECN, Melo TP. Job satisfaction among health professionals working in the Family Health Strategy. Texto Contexto Enferm [Internet]. 2017 [cited 2019 Jan 07]; 26(3):e2500016. Available from: https://dx.doi.org/10.1590/010407072017002500016

27. Chueiria P S, Harzheima E, Takeda SMP. Coordenação do cuidado e ordenação nas redes de atenção pela Atenção Primária à Saúde - uma proposta de itens para avaliação destes atributos. Rev Bras Med Fam Comunidade. 2017;12(39):1-18.

28. Silva SCPS, MAP Nunes, Santana VR, Reis FP, Machado Neto J, Lima SO. Burnout syndrome in professionals of the primary healthcare network in Aracuju, Brazil. Ciênc Saúde Colet [Internet]. 2015 [cited 2018 Oct 07];20(10):3011-20. Available from: https://dx.doi.org/10.1590/1413812320152010.19912014

29. Caçador BS, Brito MJM, Moreira DA, Rezende LC, Vilela GS. Being a nurse in the Family Health Strategy programme: challenges and possibilities. Rev Min Enferm [Internet]. 2015 [cited 2018 Oct 02];19(3):620-6. Available from: https://dx.doi.org/10.5935/1415-2762.20150047

30. Morais AJD, Teles CB, Rocha LF, Silveira MF, Pinho L. Síndrome de Burnout em médicos de estratégia saúde da família de Montes Claros, MG, e fatores associados. Rev Bras Med Fam Comunidade [Internet]. 2018 [cited 2019 June 08];13(40):1-15. Available from: https://dx.doi. org/10.5712/rbmfc13(40)1751

31. Jakovljevic M. Resilience, psychiatry and religion from public and global mental health perspective. Dialogue and cooperation in the search for humanistic self, compassionate society and empathic civilization. Psychiatr Danub [Internet]. 2017 [cited 2019 June 02];29(3):238-44. Available from: https://dx.doi.org/10.24869/psyd.2017.238 
32. Freitas PH, Beck CLC, Viero V, Fernandes MNS, Machado KL. Defensive strategies used by nurses in the Estratégia Saúde da Família to cope with distress. Texto Contexto Enferm [Internet]. 2016 [cited 2019 Jan 21];25(4):e3050014. Available from: https://dx.doi.org/10.1590/010407072016003050014

33. Rodrigues AL, Barrichello A, Morin EM. Os sentidos do trabalho para profissionais de enfermagem: um estudo multimétodos. Rev Adm Empres [Internet]. 2016 [cited 2019 Feb 05];56(2):192-208. Available from: https://dx.doi.org/10.1590/S0034-759020160206

34. Gottardo LFS, Ferreira MC. Suporte social, avaliações autorreferentes e bem-estar de profissionais de saúde. Arq Bras Psicol [Internet]. 2015 [cited 2019 Feb 20];67(1):146-60. Available from: http://pepsic.bvsalud.org/pdf/arbp/v67n1/11.pdf

35. Cherry KE, Sampson L, Gale AS, Marks LD, Stanko KE, Nezat PF, et al. Spirituality, humor, and resilience after natural and technological disasters. J Nurs Scholarsh [Internet]. 2018 [cited 2019 June 11]; 50(5):1-11. Available from: https://dx.doi.org/10.1111/jnu.1240

36. Cardoso DB, Muniz RM, Arrieira HO, Viegas AC, Arrieira ICO, Amaral DED. Women survivors of breast cancer: strategies for promotiong resilience. J Fundam Care Online [Internet]. 2018 [cited 2019 June 12];10(2):474-84. Available from: https://dx.doi.org/10.9789/2175-5361.2018. v10i2.474-484 


\section{NOTES}

\section{ORIGIN OF ARTICLE}

Extracted from the thesis - Meanings of work and resilience: experiences of professionals from the Family Health Strategy, presented to the Programa de Pós-graduação em Enfermagem, Universidade Federal de Minas Gerais, in 2018

\section{AUTHOR CONTRIBUTION}

Study design: Costa IP, Brito MJM.

Data collection: Costa IP.

Analysis and interpretation of the data: Costa IP.

Discussion of results: Costa IP, Moreira DA.

Writing and / or critical review of content: Costa IP, Moreira DA, Brito MJM.

Review and approval of the final version of the article: Costa IP, Moreira DA, Brito MJM.

\section{ACKNOWLEDGMENT}

The Coordination for the Improvement of Higher Education Personnel (CAPES), for the Interinstitutional Doctorate Agreement (DINTER) confirmed by the Federal University of Minas Gerais (UFMG) and the Federal University of Campina Grande (UFCG), agreement No. 002/15-00-Process. 23072.000348/201543, effective 2015-2019. National Council for Scientific and Technological Development (CNPq), for the productivity grant process 302896/2016, effective 2017-2020; Research grant process 409098/2018, effective 2019-2022.

\section{APPROVAL OF ETHICS COMMITTEE IN RESEARCH}

Approved by the Research Ethics Committee of the Universidade Federal de Minas Gerais, opinion 1,886,483. CAAE 62561916.1.0000.5149.

\section{CONFLICT OF INTERESTS}

There is no conflict of interest.

\section{HISTORICAL}

Received: March 31, 2019.

Approved: June 28, 2019.

\section{CORRESPONDING AUTHOR}

lluska Pinto da Costa

lucosta.ufcg@gmail.com 